ЛІТВІНОВА

Ірина Феофанівна irina_litvinova@ukr.net
УДК [343:343.359.2](045)

МІЖНАРОДНИЙ ДОСВІД ТА ПРІОРИТЕТНІ НАПРЯМКИ БОРОТЬБИ 3 УХИЛЕННЯМ ВІД СПЛАТИ ПОДАТКІВ, ЗБОРІВ ТА ІНШИХ ОБОВ'ЯЗКОВИХ ПЛАТЕЖІВ В УКРАЇНІ

\section{INTERNATIONAL EXPERIENCE AND PRIORITY DIRECTIONS OF COMBATING TAX EVASION, TAXES AND OTHER MANDATORY PAYMENTS IN UKRAINE}

к.ю.н., доцент, Національний авіаційний університет (юридичний факультет)
СОЛОМ'ЯНИЙ

Юрій Вікторович

0731588103@ukr.net студент, Начіональний авіаційний університет юридичний факультет)

LITVINOVA Iryna Feofanivna - PhD in Law, Associate Professor, National Aviation University (Faculty of Law)

SOLOMIANYI Yurii Viktorovych - student, National Aviation University (Faculty of Law)

У статті проаналізовано законодавство деяких зарубіжних краӥн щзодо відповідальності за злочини у сфері оподаткування. Встановлено, щзо загалом розвинені крайни побудували надійні системи заходів забезпечення надходження податків до державного бюджету і застосовують дієві механізми притягнення до відповідальності за порушення вимог законодавства y галузі оподаткування. Визначено, що в законодавстві розвинутих зарубіжних краӥн за ухилення від сплати податків передбачено різні види відповідальності як наслідок антифіскальної поведінки платника податків: иивільну, адміністративну та кримінальну. Запропоновано, ше для подолання проблеми, необхідно впровадити (за деякими видами порушень) залежність розміру фінансових санкцій від характеристики податкового правопорушення, його величини у грошовому вираженні, наявності чи відсутності наміру ухилення від оподаткування тощьо.

$* * *$

В статье проанализировано законодательство некоторых зарубежных стран об ответственности за преступления 6 сфере налогообложения. Установлено, что в целом развитые страны построили надежные системы мер обеспечения поступления налогов в государственный бюджет и применяют эффективные механизмы привлечения к ответственности за нарушение требований законодательства в области налогообложения. Определено, что в законодательстве развитых зарубежных стран за уклонение от уплаты налогов предусмотрены различные виды ответственности как следствие антифискального поведения налогоплательщика: гражданскую, административную и уголовную. Предложено, что для решения проблемы необходимо внедрить (по некоторым видам нарушений) зависимость размера финансовых санкций от характеристики налогового правонарушения, его величины в денежном выражении, наличия или отсутствия умысла уклонения от налогообложения и тому подобное.

$* * *$

Introduction. The paper analyzes the legislation of some foreign countries on liability for crimes in the field of taxation.

Purpose. It is established that, in general, developed countries have built reliable systems of measures to ensure tax revenues to the state budget and apply effective mechanisms to prosecute for violating the requirements of tax legislation.

Results. It is determined that the legislation of developed foreign countries provides for different types of liability for tax evasion as a consequence of anti-fiscal behavior of the taxpayer: civil, administrative and criminal. The main destabilizing factors affecting the effectiveness of tax control are: insufficient unification of domestic tax legislation with international; lack of comprehensive methods of assessment and systematic monitoring of control and verification work of tax authorities; imperfect methodological support of procedural issues of tax control, low level of its automation; lack of approaches to harmonization of relations between participants of the control and verification process; institutional distortions and distortions regarding the tax culture, discipline and consciousness of taxpayers due to the growth of the tax burden and transaction costs in the system of tax administration.

Conclusions. Domestic tax control is characterized by a tendency to converge with European requirements, but the pace of reform of the tax administration system in Ukraine is too slow. It is suggested that to overcome the problem, it is necessary to introduce (for some types of violations) the dependence of the size of financial sanctions on the characteristics of the tax offense, its value in monetary terms, the presence or absence of intent to evade taxation and so on. Finally, abandon the link between the size of financial sanctions and the economically outdated value of the tax-free minimum income; to provide financial responsibility of legal entities for conducting accounting and tax accounting with violations (the current domestic legislation provides insignificant fines for bringing to administrative responsibility only officials of the taxpayer-legal entity).

Ключові слова: відповідальність за правопорушення у сфері оподаткування, суб'єкти кримінальної відповідальності, платник податку, ухилення від сплати податків, зборів та інших обов'язкових платежів

Ключевые слова: ответственность за правонарушения в сфере налогообложения, субъекты уголовной ответственности, налогоплательщик, уклонение от уплаты налогов, сборов и других обязательных платежей

Keywords: liability for tax offenses, criminal liability, taxpayer, tax evasion, fees and other mandatory payments 


\section{ВСТУП}

Ухилення від сплати податків призводить до розвитку низки негативних тенденцій у державі: порушення правил чесної конкуренції, зростання корупції, збільшення сектору «тіньової» економіки, відтоку капіталів за кордон тощо. Державний бюджет недоотримує кошти, внаслідок чого скорочуються витрати, не фінансуються деякі державні програми, не виплачується заробітна плата працівникам бюджетної сфери. Президент, парламент, уряд і регіональні органи влади постійно підкреслюють необхідність боротьби 3 цим явищем, розробляють заходи, спрямовані на зменшення його масштабів, які, однак, не завжди приводять до належних результатів.

Міжнародний досвід свідчить, що ця проблема $\epsilon$ актуальною і для держав з розвинутою економікою, ефективною правовою системою та високим рівнем суспільної правосвідомості. Тому можна констатувати, що вона буде актуальною не лише сьогодні, але і в перспективі.

3 метою запобігання та протидії податковим злочинами використовуються різноманітні заходи - організаційні, економічні, виховні, правові. Істотне місце серед них займають заходи кримінальної відповідальності до осіб, які ухиляються від сплати обов'язкових внесків державі.

Кримінально-правовим проблемам ухилення від сплати податків присвячені роботи вітчизняних і зарубіжних вчених, як: П.П. Андрушка, В.I. Антипова, Л.П. Брич, М.Б. Бучко, В.Н. Вересова, Б.В. Волженкіна, П.Т. Геги, Д.І. Голосниченка, А.С. Гутника, Н.О. Гуторової, І.М. Даньшина, В.С. Еминова та ін.

МЕТА статті - на основі аналізу законодавства деяких зарубіжних країн стосовно відповідальності за злочини у сфері оподаткування вдосконалювати вітчизняну систему податкового контролю $з$ урахуванням вищезазначеного досвіду розвинених країн.

\section{МЕТОДИ ДОСЛІДЖЕННЯ}

Для досягнення поставленої мети і завдань, забезпечення достовірності отриманих результатів та висновків використано систему методів наукового пізнання. Порівняльно-правовий метод сприяв розгляду і дослідженню законодавства деяких зарубіжних країн та вітчизняного законодавства стосовно відповідальності за злочини у сфері оподаткування. Використання методів аналізу та синтезу сприяло узагальненню юридичної практики, аналізу емпіричної інформації, пов'язаної з темою статті. Формальноюридичний метод застосовано під час дослідження нормативних джерел.

\section{РЕЗУЛЬТАТИ}

У першому розділі даної роботи досліджено законодавство у сфері оподаткування окремих зарубіжних країн, адже без розуміння того, як в тій чи іншій державі регламентуються податкові відносини, розуміння різних підходів до боротьби з ухиленням від сплати податків буде неповним.

Розвинені країни, що закріпили панівне становище у світовій економіці, побудували надійні системи заходів забезпечення надходження податків до державного бюджету і застосовують дієві механізми притягнення до відповідальності за порушення вимог законодавства у галузі оподаткування.

Слід зазначити, що правова система України, не дивлячись на соціалістичне минуле, ближча до сім’і континентального права (романо-германська правова система). Так, ст. 8 Конституції України закріплено принцип верховенства права, а нормативно-правові акти є основним джерелом права. Розглянемо відповідальність за податкові правопорушення саме у таких країнах, як Франція, Німеччина. Також буде приділено увагу прикладам боротьби з податковою злочинністю у деяких країнах сім’ї загального права, таких як США, Великобританія, Канада.

Тож звернемося до зарубіжного досвіду діяльності податкових органів, що утворені у цих країнах для боротьби з податковими правопорушеннями.

Найважливішим аспектом податкового законодавства $\epsilon$ те, що в ньому не діє принцип презумпції невинності й вага доказів у розгляді судових позовів за податковими справами завжди лежить на платниках податків. Обвинувачений (підозрюваний) водночас не має права на відмову віддачі свідчень, які можуть бути використані проти нього у ході судового розгляду. Схожі правові норми діють у США, Франції, Німеччині, Швейцарії та деяких інших країнах.

Судова практика найкрупніших країн Заходу свідчить про те, що злочини у фінансовій сфері практично завжди $є$ "консенсусними", тобто здійснюються за попередньою домовленістю сторін (наприклад, між суб'єктами оподаткування або між ними і корумпованими представниками влади). Водночас використовується як недосконалість законодавчих актів і "допомога" корумпованих чиновників, так і традиційні способи ухилення від сплати податків шляхом приховування прибутків, проведення складних міжбанківських комбінацій і багатоканального "трасування" грошей у різні сфери тіньової економіки. Спеціалісти відзначають складність документування і формування доказової бази подібних злочинів, оскільки основні учасники протиправних дій глибоко законспіровані, а їх дії, як правило, ретельно сплановані і добре організовані.

Тому у більшості західних країн податкові судові позови виключені зі сфери майнових позовів і по суті прирівняні до карних справ. Відповідно за навмисне приховування прибутків від оподаткування законодавством передбачені такі ж суворі покарання, як і за карні злочини.

Специфіка податкового законодавства і складність судового розгляду справ про правопорушення у податковій сфері обумовили створення у деяких західних країнах, наприклад, у Німеччині, інституту "податкових судів", які, діючи в загальних рамках системи юстиції, займаються виключно розглядом позовів із податкових питань. У цих же судових органах можуть бути оскаржені рішення податкових властей про застосування фінансових санкцій (про накладення штрафу, арешту на майно тощо).

Прерогатива створення правової основи податко- 
вих систем, визначення податкової бази (види податків і категорії платників податків), а також рівня податкових ставок належать вищим законодавчим органам країн, які розглядаються. Компетенція місцевих влад у податковій сфері, зокрема відносно введення нових податків або зміни існуючого порядку оподаткування на тій чи іншій території визначається загальнодержавними законами (у федеральних державах федеральними законами).

Так, уряди штатів в США і земель у Німеччині можуть вводити нові місцеві податки або переглядати рівень податкових ставок лише у рамках повноважень, визначених федеральними законами цих країн.

Функція збору податків і контролю за правильністю і повнотою їх стягнення покладена на спеціальні податкові служби центральних і місцевих органів влади. На рівні центральних влад вони представлені, як правило, податковим управлінням у складі міністерства фінансів (США, Німеччина, Франція) або відокремленими державними органами (наприклад, Національна податкова адміністрація в Японії). На регіональному і місцевому рівнях діють фінансові управління, податкові інспекції, податкові бюро тощо.

Фіскальні служби володіють виключно широкими правами у сфері контрольно-інспекційної діяльності. У тих випадках, коли податкова інспекція не задоволена відомостями, які зазначені в декларації про прибутки, вона може вимагати будь-яку іншу додаткову інформацію про платника податків (за місцем його роботи, в банку, страховій компанії тощо) або назначити ревізію бухгалтерських книг та інших фінансових документів за декілька років. За результатами ревізії сума податку може бути переглянута: у Швейцарії - за останні 3 роки, в США - за 5 років, в Німеччині - (за наявності підозр у навмисному приховуванні прибутків) - за 10 років.

Одним із розповсюджених прийомів, які застосовуються правоохоронними та податковими органами для виявлення фактів приховування прибутків, $є$ співставлення задекларованих прибутків з реальними витратами платника податків. Для цього підраховуються його крупні придбання за декілька років (купівля нерухомості, автомашини, капіталовкладення, цінні папери тощо) і порівнюються із вказаними у податковій декларації офіційними прибутками за той самий період. Значні розбіжності між сумами прибутків і витрат можуть служити основою для проведення фінансового розслідування і відкриття судової справи за звинуваченнями в ухиленні від сплати податків.

Необхідно зазначити, що всеохоплюючий контроль над грошовими операціями населення зі сторони податкових служб, а через них і зі сторони правоохоронних органів, став можливим лише на основі бурного розвитку систем безготівкових розрахунків 3 широким використанням електронно-обчислювальної техніки. До середини 80-х pp. ХХ ст. процес автоматизації безготівкових розрахунків у банківському обслуговуванні населення, торгівлі та комунальнопобутовій сфері загалом завершився. Основною формою платежів у таких країнах, як США, ФРН, Англія, Франція, Японія, Канада та ряді інших країн стало використання пластикових кредитних карток. У США, наприклад, лише 3 \% розрахунків за товари і послуги здійснюється за готівку, причому 75 \% 3 них припадає на платежі у сумі менше 1 дол. До початку 90-pp. XX ст. на виплату заробітної плати через банківські рахунки було переведено 99 \% робочих і службовців у США і Канаді, 95 \% - в Англії.

У цих умовах будь-яка платіжна операція з чеком, кредитною карткою, грошовим переказом, акцією, облігацією залишає "слід" у пам'яті комп'ютера. Вказана обставина, на думку спеціалістів із боротьби 3 ухиленням від сплати податків, істотно ускладнює обіг фінансових коштів в "тіньовому" секторі економіки, спонукаючи представників тіньового бізнесу відкривати нові, більш вишукані способи легалізації прибутків, отриманих з незаконних джерел.

У Німеччині відповідальність за більшість податкових злочинів передбачена в галузевому законодавчому акті, виняток становить відповідальність за підробку знаків сплати мита та розголошення податкової таємниці, встановлена в Кримінальному кодексі ФРН. Стосовно складів, передбаченим у Положенні про порядок справляння податків, норми Кримінального кодексу застосовуються субсидіарно.

Види податкових злочинів прямо перераховані у Положенні про порядок справляння податків, водночас звертає на себе увагу тотожність понять митного та податкового злочину.

До податкових злочинів за законодавством ФРН відносяться:

1) злочини, карні згідно з податковими законами, найперше ухилення від сплати податків і контрабанда;

2) порушення митних правил;

3) підроблення знаків сплати і готування до такого підробці, оскільки діяння стосується знаків сплати мита;

4) приховування особи, яка вчинила одне 3 перерахованих злочинів.

Поняття "ухилення від сплати податків" визначається у законодавстві ФРН через перерахування конкретних способів його вчинення, а саме: подання недостовірних або неповних відомостей, умисне неподання відомостей, умисне незастосування знаків сплати мита або податкових штампів, при цьому обов'язковою ознакою злочину є настання шкідливих наслідків - заниження розміру обов'язкових платежів або отримання невиправданих податкових переваг.

У Франції склади злочинів, пов'язаних з порушенням податкового законодавства, встановлені у Спільному податковому кодексі. У ньому окремо регулюється відповідальність: за правопорушення стосовно всіх видів податків; правопорушення, пов'язані з прямими податками; правопорушення стосовно податків 3 обороту; правопорушення, пов'язані 3 непрямими податками; правопорушення стосовно реєстраційних та гербових зборів [1, с.407].

Основною формою такого злочину як ухилення від сплати податків є несплата податку, яка може бути здійснена у т.ч. шляхом обману, неподання декларацій, приховування оподатковуваної суми, організації несплати сум податку. До злочинів, пов'язаних з усіма видами податків, відносяться: письмові упущення чи неточності, помилкові записи у бухгалтерських книгах про фінансові операції; організація колективного відмови від сплати податків шляхом насильницьких дій, погроз, а також підбурювання до несплати подат- 
ків або затримки сплати; протидія агентам, уповноваженим проводити фінансові перевірки, у здійсненні ними своїх функцій.

До числа кримінально караних діянь у сфері прямого оподаткування відносяться: відмова від платежів або помилка, навмисне допущена у платежах; приховування доходів, що надходять 3-за кордону; неточне складання документів 3 метою зниження податків. Слід зазначити, що до кримінальної відповідальності можуть бути притягнуті не тільки платники податків, а й фахівці (наприклад, бухгалтери), які в силу своїх обов'язків на професійній основі складають звіти і баланси своїх клієнтів.

У сфері непрямих податків кримінально караними $\epsilon$ дії, спрямовані на контрабандний ввіз і вивіз алкогольних та спиртовмісних напоїв, тютюнових виробів, пороху, сірників, фосфору.

До злочинів, пов'язаних 3 реєстраційними і гербовими зборами, відносяться в т.ч. помилкове твердження з метою зниження вартості передається або спадщини, порушення поточних гербових зборів, використання i продаж вже використаних гербових марок.

Найбільшого поширення в якості санкцій за вчинення злочинів, пов'язаних 3 порушенням податкового законодавства, отримали штрафи і позбавлення волі.

Водночас можливо також застосування додаткових покарань, до яких відносяться опублікування вироку у певних виданнях, позбавлення повністю або частково на певний строк цивільних прав, права займатися комерційною або промисловою діяльністю, заборона брати участь у прилюдних торгах та деякі інші.

У Великобританії не проводиться формального розмежування між злочинами і провинами, а з 1967 р. скасовані всі відмінності між фелонією та місдімінором. У літературі правопорушення у сфері оподаткування, відповідальність за які передбачена законодавством Великобританіі, пропонують розділити на наступні групи:

1. Навмисні діяння, або діяння, вчинені з недбалості, результатом яких стає введення податкових органів в оману: направлення у податкові органи невірної податкової декларації; подання недостовірної інформації, заяви чи податкової декларації у зв'язку з розглядом позову про сплату податків; уявлення інспектору або іншим уповноваженим службовцям недостовірних рахунків у зв'язку 3 виконанням обов'язку зі сплати податків;

2. Шахрайські дії, які полягають у наданні неправдивої інформації з метою отримання податкової пільги;

3. Дії, спрямовані на ухилення від сплати мита: неправильне заповнення митної декларації та умисне приховування інформації про експортованих та імпортованих товарах; незаконний імпорт або експорт і пов'язане $з$ цим ухилення від сплати мита;

4. Шахрайські дії, які полягають у незаконному виготовленні гербових марок, призначених для податкових органів, або ї підробка, умисне надання допомоги у таких діях, а також продаж фальшивих гербових марок.

Податкові правопорушення у Великобританії мо- жуть вчинятися шляхом дії або бездіяльності. За загальним правилом особа може бути притягнута до відповідальності за вчинення правопорушення шляхом бездіяльності тільки в тому випадку, коли така можливість прямо передбачена законом.

Притягнення до відповідальності припускає накладення на осіб, які вчинили правопорушення, додаткових заходів поряд зі сплатою відповідних сум податків. В якості можливих санкцій у законодавстві Великобританії передбачені штраф і позбавлення волі [2, с. 143].

Слід зазначити, що податкові служби у західних країнах значною мірою наділені повноваженнями правоохоронних органів. Органи податкових розслідувань (слідчий апарат) по суті являють собою спеціалізовані поліцейські служби, які часто використовують у проведенні фінансових розслідувань такі специфічні методи, як негласне спостереження, опитування свідків із оточення підозрюваної особи, перлюстрація поштових відправлень і прослуховування телефонних розмов, залучення платних інформаторів. Співробітники органів податкових розслідувань часто проводять розслідування негласно, використовуючи в якості прикриття документи різних урядових і навіть приватних організацій.

Таким чином, наділення податкових служб західних країн деякими правами і функціями правоохоронних органів, зокрема створення у рамках цих служб підрозділів податкових розслідувань, які використовують специфічні методи роботи, характерні для спецслужб, дозволяє істотно підвищити ефективність фінансового контролю в області оподаткування. 3 іншого боку, тісна взаємодія податкових органів з правоохоронними та спецслужбами насамперед по лінії обміну інформацією сприяє помітній боротьбі 3 іншими, загально кримінальними видами злочинності.

Згідно з канадським законодавством податкове порушення набуває кримінального характеру у випадку, коли воно пов'язане з умисним наміром обманути податкове відомство з метою зменшення податкових зобов'язань чи одержання незаконного відшкодування податків із бюджету.

Відповідальність за протиправні дії у сфері оподаткування передбачає покарання у вигляді штрафу у розмірі не менше $50 \%$ і не вище $200 \%$ від суми прихованого податку, або на додаток до штрафу ще й позбавлення волі на термін до двох років. Найбільш небезпечні податкові злочини, пов'язані 3 несплатою податків на суму більше 5 тис дол., можуть каратися тюремним ув'язненням на термін до 10 років.

Слідчі дії з податкових правопорушень, покарання за які не перевищує двох років позбавлення волі, веде Управління розслідувань, що входить до структури Агентства державних доходів. В інших випадках дізнання віднесено до компетенції Королівської кінної поліції Канади (кримінальної поліції) [3, с. 354].

За кордоном все більшого поширення отримує погляд, згідно з яким концентрація зусиль на безпосередній боротьбі проти порушників податкових законів малоперспективна і не результативна. Необхідне перенесення уваги на використання заходів профілактичного характеру реформування облікової роботи, зміцнення та вдосконалення механізмів превен- 
тивного контролю, виховання податкової етики та самодисципліни платників податків.

Радикальне покращення ситуації у цій сфері, як показує досвід передових розвинених країн, досягається за рахунок забезпечення більшої рівності і справедливості у системі оподаткування, за рахунок загального спрощення податкової системи і застосовуваних методів оподаткування і звітності та в результаті зниження невиправдано високих ставок окремих податків і скорочення загального податкового тягаря населення [4].

Зокрема, сьогодні не достатньо застосовуються непрямі методи.

Насамперед це стосується методу «горизонтального моніторингу», застосування якого мало успіх у Нідерландах, Німеччині, Австрії, Великобританії, Ірландії, Словенії, Південній Кореї, і допомогло б мінімізувати втручання у поточну діяльність суб'єктів великого бізнесу, забезпечивши тим самим повноцінне наповнення бюджетів усіх рівнів з одночасним дотриманням балансу прав контролюючих органів і платників податків.

Горизонтальний моніторинг - це здійснення процедури відстеження та аналізу контролюючим органом податкових ризиків, проведених і запланованих великим платником податків фінансово-господарських операцій. Цей метод базується на співпраці між податковими органами та великими платниками податків шляхом збільшення взаємної відповідальності, створення культури консультування, підвищення рівня співробітництва та довіри задля створення партнерських взаємовідносин між податковими органами та великими платниками податків шляхом своєчасного реагування та попередження здійснення ними ризикових операцій, що можуть призвести до порушень податкового, валютного та іншого законодавства, контроль за яким здійснюється податковими органами.

Горизонтальний моніторинг допомагає попередити здійснення платником податків ризикових операцій і визначити фактор, що їх зумовлюють. Інакше кажучи, відповідна Спеціалізована державна податкова інспекція з обслуговування великих платників за згоди платника податків безкоштовно опрацьовує інформацію про його фінансові операції та наперед вказує на можливі ризикові розрахунки й операції, а також на сумнівних контрагентів, що їх здійснюють.

Впровадження горизонтального моніторингу надасть змогу розпочати формування ефективної для бюджету та необтяжливої для сумлінних платників податків системи адміністрування податків у рамках проведення податкової реформи та досягти мінімізації втручання у поточну діяльність платників податків, оперативного реагування податкового органу на проблеми суб'єктів оподаткування, заміни наявного постаудиту платника податків поточним моніторингом діяльності, удосконалення ризикоорієнтованої системи адміністрування податків, запровадження принципу довіри між податковими органами та великим бізнесом.

3 огляду на відсутність відповідного законодавства та високий рівень корупції в Україні оцінки стосовно успішного впровадження цього проекту у вітчизняну практику здійснення податкового контролю наразі залишаються доволі скептичними.

Основні переваги застосування горизонтального моніторингу:

1. Мінімізація втручання податкових органів у поточну діяльність платника податків та оперативне реагування на його проблеми, зокрема шляхом надання ефективних консультацій у разі його звернення.

2. Запровадження принципу взаємодовіри у відносинах між податковими органами та платниками податків i, як наслідок, суттєве зменшення кількості, а надалі, можливо, і повна відсутність планових і позапланових перевірок [3, с.278].

Водночас із врахуванням існуючої ситуації у державі даний метод має певні недоліки:

1. Відсутність в Україні відповідного законодавства. Зокрема, не передбачено права фіскальних органів на укладення 3 платниками податків меморандумів стосовно здійснення горизонтального моніторингу; обов'язку фіскального органу дотримуватися зобов'язань, встановлених названим меморандумом, зокрема зобов'язань щодо звуження обсягу перевірок і надання податкових консультацій у прискореному режимі.

2. Відсутність формальних умов (вимог) для застосування горизонтального моніторингу. Сдина вимога полягає у тому, що підприємство має контролювати власне адміністрування податків. Усунути цю невизначеність можна шляхом запровадження так званих заяв про контроль за податками (як, наприклад, у Великобританії).

Недоліки здійснення горизонтального моніторингу можуть бути ліквідовані шляхом впровадження контролю за податками як законодавчої вимоги із одночасним скасуванням угод про дотримання вимог і забезпечення рівного ставлення до різних за статусом компаній.

Крім того, враховуючи певний вплив розміру фінансових санкцій на масштаби ухилення від оподаткування і значення виконання карної функції податкового контролю необхідно й далі вдосконалювати систему фінансових санкцій, враховуючи вітчизняний, а також прогресивний європейський досвід.

Зокрема, на даний час доцільно:

- остаточно відмовитися від прив'язки розміру фінансових санкцій до економічно застарілого значення неоподаткованого мінімуму доходів громадян;

- впровадити (за деякими видами порушень) залежність розміру фінансових санкцій від характеристики податкового правопорушення, його величини у грошовому вираженні, наявності чи відсутності наміру ухилення від оподаткування тощо;

- передбачити фінансову відповідальність юридичних осіб за ведення бухгалтерського і податкового обліку з порушеннями (чинним вітчизняним законодавством передбачені незначні розміри штрафів під час притягнення до адміністративної відповідальності лише посадових осіб платника податків-юридичної особи).

Таким чином, законодавство, що регламентує кримінальну відповідальність за ухилення від сплати податків, зборів та обов'язкових платежів в Україні знаходиться на стадії перехідного періоду. 
На сьогодні воно все ще залишається не пристосованим до умов ринкової економіки, що ще більше посилюється впливом кризових явищ в політиці та економіці. Але у ході свого розвитку податкові та кримінальні норми набувають нових особливостей, що призводить до виникнення суперечностей в реалізації даних норм контролюючими та судовими органами.

У будь-якому разі на Україну чекає ще багато змін у правовій сфері. Як відносно молода і незалежна держава, Україна має чудову можливість, розвиваючи власну правову систему, ввібрати в себе все те найкраще від вже існуючих правових систем, та податкових систем, зокрема, що пройшло перевірку часом, використовуючи їх багатовіковий досвід.

\section{Список використаних джерел}

1. Загородній А.Г., Вознюк Г.Л. Фінансово-економічний словник. Львів: Вид-во НУ «Львівська політехніка», 2005. $714 \mathrm{c}$.

2. Думчиков М.О. Зарубіжний досвід краӥн Свропейського Союзу у сфері удосконалення системи оподаткування та доиільність його застосування в Україні. Науковий вісник Херсонського державного університету. 2017. № 4. C. $142-148$

3. Якушик І.Д., Литвиненко Я.В. Податкові системи зарубіжних краӥн: довідник. Київ: «МП Леся», 2004. 480 с.

4. Етерис Ю. Теневая економика: позичия Евросоюза. URL: http://www.baltic-course.com/rus/kruglij_stol/?doc $=1029$

\section{References}

1. Zahorodnii A.H., Vozniuk H.L. Financial and economic dictionary. Lviv: Lviv Polytechnic National University Publishing House, 2005. 714 p. [in Ukrainian]

2. Dumchykov M.O. Foreign experience of the European Union in the field of improving the taxation system and the feasibility of its application in Ukraine. Scientific Bulletin of Kherson State University. 2017. № 4. pp. 142-148. [in Ukrainian]

3. Yakushyk I.D., Lytvynenko Ya.V. Tax systems of foreign countries: guide. Kyiv: «MP Lesia», 2004. 480 p. [in Ukrainian]

4. Eterys Yu. Shadow economy: the position of the European Union.URL: http://www.baltic-course.com/rus/ kruglij_stol/?doc $=1029$. [in Russian] 